\title{
Role of unsaturated soil above a heavily contaminated aquifer in the natural attenuation of arsenic
}

\author{
Nadia Martínez-Villegas ${ }^{1, *}$, Andrea del Pilar Gómez ${ }^{1}$, Armando Zamora-Morales ${ }^{1}$, Jejanny \\ Lucero Hernández Martínez ${ }^{1}$, Diana Meza-Figueroa ${ }^{2}$, and Bhaskar SenGupta ${ }^{3}$ \\ ${ }^{1}$ IPICYT, Instituto Potosino de Investigación Científica y Tecnológica, División de Geociencias \\ Aplicadas, Camino a la Presa San José No 2055, Col. Lomas 4a sec., San Luis Potosí 78216, SLP, \\ Mexico \\ ${ }^{2}$ Departamento de Geología, Universidad de Sonora, Rosales y Encinas s/n, Col. Centro, Hermosillo \\ 83000, Sonora, Mexico \\ ${ }^{3}$ School of Energy, Geoscience, Infrastructure \& Society, Heriot-Watt University. Water Academy, \\ EGIS 2.02A William Arrol Building, EH14 4AS Scotland, United Kingdom
}

\begin{abstract}
Large attenuation of arsenic is observed in a shallow aquifer in central Mexico, where the concentration decreases from 91.5 to $11.3 \mathrm{mg} / \mathrm{L}$, over $1.3 \mathrm{~km}$ horizontal distance. To investigate possible mechanisms of attenuation of this pollutant, we dug a pit between the surface and the saturated zone. We then described the soil profile and determined arsenic and iron concentrations in soil samples as a function of depth. Next, we determined particle size distribution, bulk density, particle density, soil moisture and porosity of the soil material. We also analyzed arsenic concentration in the groundwater. The $2.2 \mathrm{~m}$ deep profile intersected 4 soil horizons ( $\mathrm{A}, \mathrm{AB}, \mathrm{B} 1$ and $\mathrm{B} 2)$. We found arsenic accumulation in the $\mathrm{B} 2$ horizon, directly overlying the saturated zone. These accumulations coincide with the thickness of the capillary fringe, revealing that arsenic is drawn up in the soil profile by capillary rise of arsenic-contaminated groundwater. Furthermore, arsenic accumulation showed a direct relationship with iron, likely due to arsenic adsorption on iron oxides. Results from this study contribute to understanding a capillary-driven natural attenuation mechanism that removes contaminants from groundwater by sinking them in the capillary fringe.
\end{abstract}

\section{Introduction}

Millions of people around the world are chronically exposed to high levels of arsenic in water with the mortal risk of suffering from various forms of cancer, among many other diseases; at least 137 million people in 70 countries consume groundwater contaminated with arsenic due to the shortage of drinking water [1]. In Latin American countries, including Mexico, Chile, Bolivia and Argentina, it is estimated that at least 4.5 million people are exposed to water contaminated with arsenic on values up to 200 times higher

\footnotetext{
*Corresponding author: nadia.martinez@ipicyt.edu.mx
} 
than the standard value of the World Health Organization $(10 \mu \mathrm{g} / \mathrm{L})[2,3]$. In Mexico alone, it is estimated that 2 million people are exposed to concentrations of arsenic in water above what is established by environmental regulations $(25 \mu \mathrm{g} / \mathrm{L})$ [4]. Due to its toxic and carcinogenic effects, and its incidence in many diseases such as diabetes and kidney damage, it is essential to offer solutions that reduce arsenic contamination. In Matehuala, San Luis Potosi, where high environmental contamination due to mining and metallurgical activities occur, large natural attenuation of arsenic has been reported in a shallow aquifer, where water arsenic contamination decreases from 91.5 to $11.3 \mathrm{mg} / \mathrm{L}$ over a $1.3 \mathrm{~km}$ distance [5]. Yet, the mechanisms controlling this attenuation are unknown. The aim of this research was to identify mechanisms of attenuation of arsenic occurring in Matehuala analysing the unsaturated and the saturated zones of a soil profile.

\section{Materials and methods}

A soil pit was dug until reaching the saturated zone (Fig. 1). Soil pit location (100.6394 N, $23.6597 \mathrm{~W}$ ) was selected to fall within an area where arsenic attenuation in groundwater had been reported previously [5]. Soil profile was described and soil classification was carried out according to the WRB system. A total of 22 soil samples were collected to determine arsenic and iron concentrations using the 6200 USEPA method based on X-ray fluorescence. Soil samples were collected every $10 \mathrm{~cm}$ along the soil profile. Soil moisture was determined in the field every $10 \mathrm{~cm}$ using a soil moisture meter Lutron PMS-714. Additionally, soil $\mathrm{pH}$ was determined in the laboratory using a Thermo-scientific potentiometer model Orion Versa Star. Particle size distribution of soil samples was determined by the Bouyoucos hydrometer method after eliminating organic matter with $\mathrm{H}_{2} \mathrm{O}_{2}$ treatment. Bulk density and particle density were determined to estimate soil porosity. Bulk soil mineralogy was determined by $\mathrm{X}$ ray diffraction (XRD) using a Smartlab diffractometer model Rigaku.

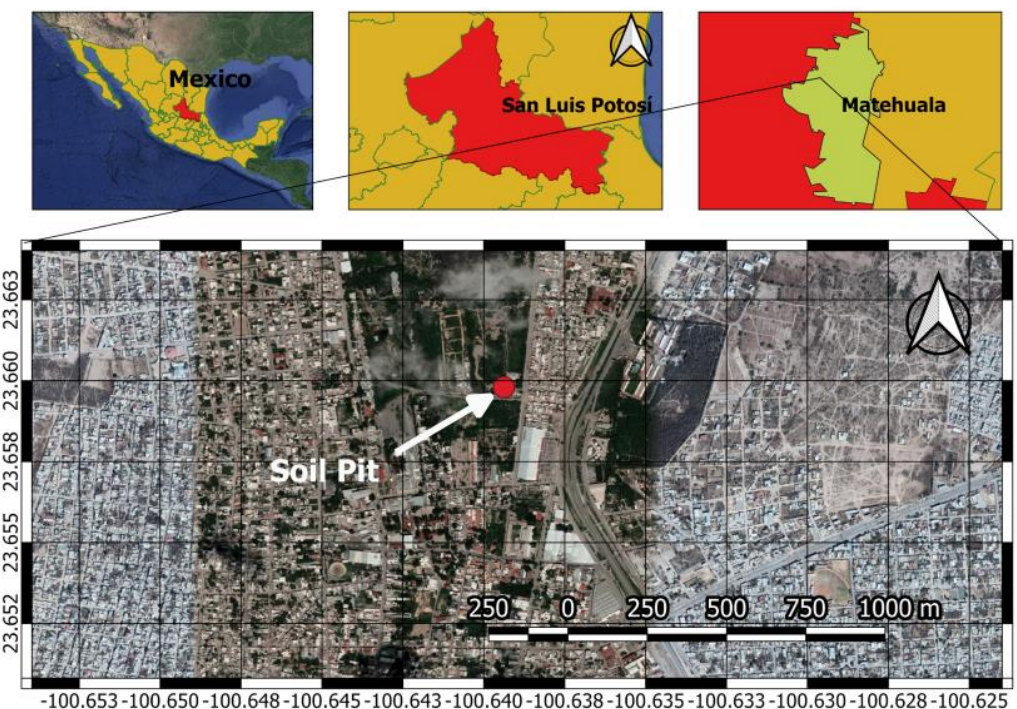

Fig. 1. Soil pit is located in Matehuala, San Luis Potosi, Mexico.

Additionally, one sample of water, from the saturated zone, was collected in an acidwashed bottle. Groundwater was filtered $(<0.45 \mu \mathrm{m})$ and acidified to $\mathrm{pH}<2$ using $\mathrm{HNO}_{3}$. The sample was hermetically sealed and stored at $4^{\circ} \mathrm{C}$ until analyses. The arsenic determination analysis was performed by inductively coupled plasma optical emission 
spectroscopy (ICP-EOS). Groundwater $\mathrm{pH}$ was measured in the field using a HANNA multiparameter model HI 9829.

\section{Results and discussion}

Table 1 shows soil horizons, depth, particle size distribution, bulk density, particle density, soil moisture and porosity. Soil profile was $220 \mathrm{~cm}$ deep, with 4 soil horizons from 0-50 cm (A soil horizon), 50-100 cm (AB soil horizon), 100-160 cm (B1 soil horizon), and 160-220 $\mathrm{cm}$ (B2 soil horizon). The soil profile corresponds to a Calcisol and overlays the saturated zone. Along the soil profile, particle soil distribution was dominated by silt, followed by sand and clay. Bulk density increased from topsoil to saturated zone, while particle density varied only from 2.45 to $2.60 \mathrm{~g} / \mathrm{cm}^{3}$. Soil moisture increased from $6.1 \%$ (very dry) to $50 \%$ (humid), from A to B2 horizon, respectively. In contrast, porosity showed an opposite trend, decreasing from A horizon $(49 \pm 0.3 \%)$ to B2 horizon $(19.3 \pm 4.8 \%)$. These results reveal a capillary fringe area that is limited by a change in soil texture between B2 and B1 soil horizons.

Table 1. Physical soil properties.

\begin{tabular}{|c|c|c|c|c|c|c|c|c|}
\hline \multirow{2}{*}{ Horizon } & \multirow{2}{*}{$\begin{array}{l}\text { Depth } \\
(\mathrm{cm})\end{array}$} & \multicolumn{3}{|c|}{$\begin{array}{c}\text { Particle size distribution } \\
(\%)\end{array}$} & \multirow{2}{*}{$\begin{array}{l}\text { Bulk density } \\
\quad\left(\mathrm{g} / \mathrm{cm}^{3}\right)\end{array}$} & \multirow{2}{*}{$\begin{array}{l}\text { Particle } \\
\text { density } \\
\left(\mathrm{g} / \mathrm{cm}^{3}\right)\end{array}$} & \multirow{2}{*}{$\begin{array}{c}\text { Soil } \\
\text { moisture } \\
(\%)\end{array}$} & \multirow{2}{*}{$\begin{array}{l}\text { Porosity } \\
(\%)\end{array}$} \\
\hline & & Clay & Silt & Sand & & & & \\
\hline A & $0-50$ & 1.4 & 58.1 & 40.5 & $1.53 \pm 0.01$ & $2.55 \pm 0.03$ & $6.1 \pm 4.0$ & $40 \pm 0.3$ \\
\hline $\mathrm{AB}$ & $50-100$ & 5.4 & 52.1 & 42.5 & $1.64 \pm 0.02$ & $2.45 \pm 0.05$ & $10.8 \pm 2.7$ & $33 \pm 0.6$ \\
\hline B1 & $100-160$ & 17.4 & 54.1 & 28.5 & $1.95 \pm 0.02$ & $2.60 \pm 0.05$ & $46.6 \pm 8.3$ & $25 \pm 1.0$ \\
\hline B2 & $160-220$ & 11.4 & 50.1 & 38.5 & $2.03 \pm 0.01$ & $2.51 \pm 0.09$ & $50.0 \pm 0.0$ & $19 \pm 4.8$ \\
\hline
\end{tabular}

Along the soil profile, soil $\mathrm{pH}$ ranged from 7.4 to 7.7 , while arsenic concentrations showed a decreasing behaviour from $100 \mathrm{mg} / \mathrm{kg}$ at $10 \mathrm{~cm}$ to $20 \mathrm{mg} / \mathrm{kg}$ at $140 \mathrm{~cm}$ (Fig. 2). This, likely due to surface deposition of arsenic contaminated particles, such as tailings, waste rock, and residues, from active and/or historical mining and/or metallurgical activities in the area $[5,6,7]$. Background concentrations of arsenic in study area ranged from 4 to $35 \mathrm{mg} / \mathrm{kg}$ [8], while the Mexican arsenic guideline for agricultural, urban and commercial soils is $22 \mathrm{mg} / \mathrm{kg}$, suggesting therefore arsenic contamination in our soil profile. After $140 \mathrm{~cm}$, arsenic concentration increased sharply up to $340 \mathrm{mg} / \mathrm{kg}$ at $160 \mathrm{~cm}$ to decrease again to $80 \mathrm{mg} / \mathrm{kg}$ in the saturated zone (Fig. 2). As subsoil contamination was as thick as the capillary fringe, increased arsenic concentrations in the subsoil were attributed to capillary rise of arsenic contaminated groundwater, from the saturated zone to the capillary fringe area. Such a process might occur in a manner similar to the formation of efflorescent salts in tailing impoundment [9], but, in this case, in a soil profile, underground, where studies are very scarce and only report the load of heavy metals and organic contaminants [10,11]. Iron concentrations ranged from 5.30 to $15.8 \mathrm{~g} / \mathrm{kg}$ showing, in general, a decreasing behaviour from A horizon to saturated zone, except for a minimum trend found at $70 \mathrm{~cm}$ (Fig. 2). Interestingly, arsenic showed a positive linear correlation to iron in the B2 horizon (Fig. 3) suggesting that, in this horizon, arsenic accumulates on iron oxides. Arsenic adsorption on iron oxides is a common in-situ mechanism of immobilization of arsenic in soils. Bulk soil mineralogy showed that presence of calcite, dolomite, gypsum, and quartz. Further studies are need to reveal the presence of iron 
oxyhydroxide minerals and/or the chemical soil fractions that effectively immobilized arsenic on soil. Such information will help to better assess the immobilization of arsenic along the soil profile.

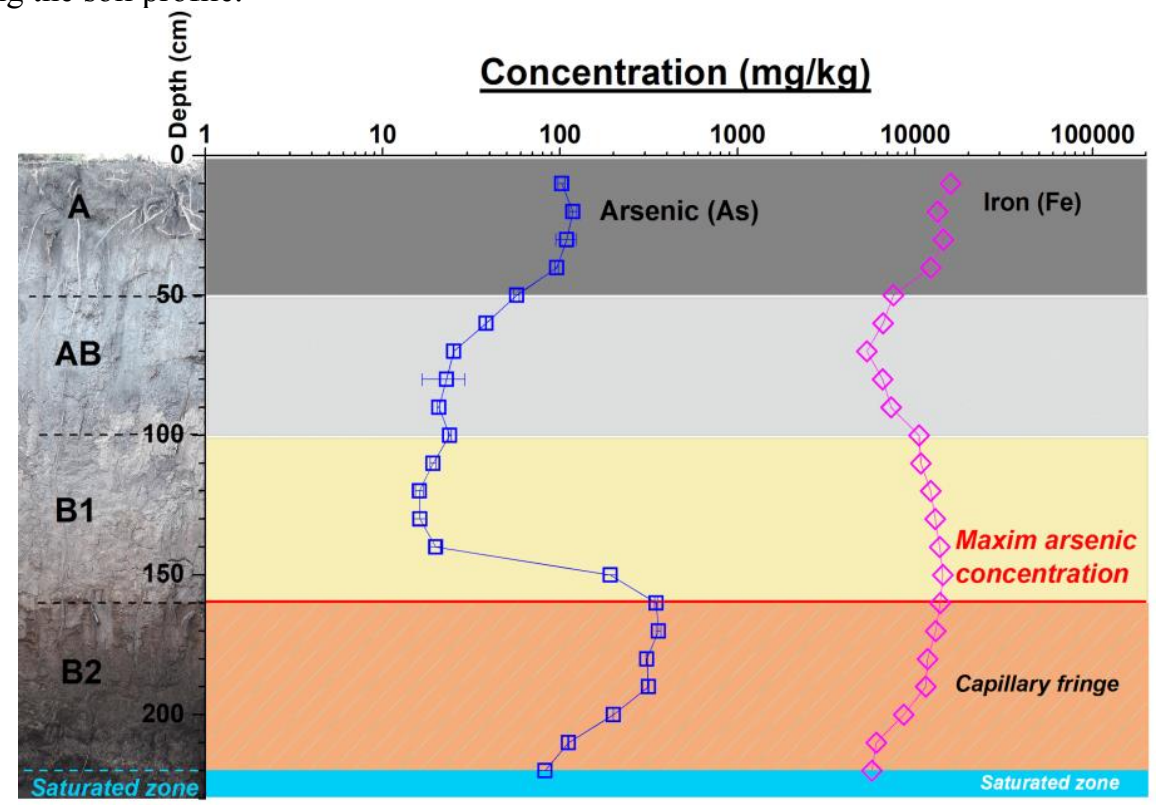

Fig. 2. Soil profile and arsenic and iron concentrations as a function of depth.

Arsenic concentration in groundwater $(60 \mathrm{mg} / \mathrm{L})$ exceeded the WHO's permissible drinking water standard, demonstrating high arsenic contamination. Groundwater $\mathrm{pH}$ was 6.02. Drawing up arsenic from the aquifer to the upper soil horizon by capillary rise of arsenic contaminated water may explain the large natural attenuation of arsenic observed in study area. Furthermore, results from this study reveal a capillarity driven natural attenuation mechanism that removes As from groundwater by sinking it in the capillary fringe, where studies are scarce and, so far, have focused on heavy metals and organic contaminants.

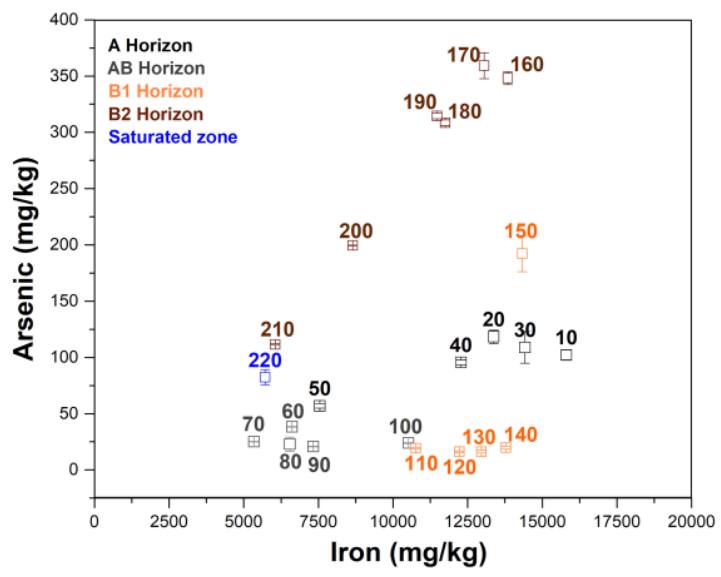

Fig. 3. Arsenic concentrations as a function of iron concentrations showing a direct relationship in the B2 soil horizon which is overlying the saturated zone. The numbers on samples are the sample depth (cm) from the surface. 
This study was funded by grant NA140182 Newton Advanced Fellowship from the Royal Society. NMV is thankful to CONACyT for Grant No. 7073. APG and JLHM are thankful to CONACYT for 588409 and 166112 graduate and postdoctoral fellowships, respectively. We thank land owners who kindly permitted access to their properties and Felipe Barraza who helped to prepare Figure 1.

\section{References}

1. P. Ravenscroft, H. Brammer, K. Richards, Arsenic pollution: a global synthesis (Wiley-Blackwell, 2009)

2. WHO, Background document for preparation of WHO Guidelines for drinking-water quality (WHO/SDE/WSH/03.04/75, 2003)

3. S. Farías, G. Bianco de Salas, R.E. Servant, B.G. Mitre, J. Escalante, R.I. Ponce, Arsenic in the environment (I. Chapter 41, J. Bundschuh y P. Bhattacharya, Eds. 2008)

4. DOF, Modificación a la Norma Oficial Mexicana NOM-127-SSA1-1994, salud ambiental. Agua para uso y consumo humano. Límites permisibles de calidad y tratamientos a que debe someterse el agua para su potabilización (Secretaría de Salud, México, DF 2000)

5. N. Martínez-Villegas, R. Briones-Gallardo, J.A. Ramos-Leal, M. Avalos-Borja, A.D. Castañón-Sandoval, E. Razo-Flores,M. Villalobos, Environ. Pollut. 176 (2013)

6. I. Razo, L. Carrizales, J. Castro, F. Díaz-Barriga, M. Monroy, Water. Air. Soil Pollut. 152, 1-4 (2004)

7. M. Manz, L. J. Castro, Environ. Pollut. 98, 1 (1997)

8. J.A. Chiprés, J. Castro-Larragoitia, M.G. Monroy, Appl. Geochem. 24, 8 (2009)

9. D. Nordstrom, Mine Water and Environment (IMWA Proceedings 1999)

10. Z. Kurt, E.E. Mack, J.C. Spain, Environ. Sci. Technol. 50 (2016)

11. K. Prade, V. Hagelgans, T. Scwhieger, Bodenk. u. Pflanzenernähr 154 (1991) 